\title{
Changes in forest diversity over a chronosequence of fluvial islands
}

\author{
Federico Brumnich ${ }^{(1-2)}$, \\ Zuleica Yael Marchetti ${ }^{(1-2)}$, \\ María Soledad Pereira ${ }^{(2)}$
}

\begin{abstract}
The high environmental heterogeneity of large fluvial systems is reflected by the co-existence of contrasting plant communities and landforms. The main objective of this study was to assess the forest diversity changes in islands of the Middle Paraná River (Argentina) in order to discuss an integrative question: how synchronized are the major changes in the features of islands and forests? Persistence age, elevation and flood regime of 11 main channel islands were determined. Variables related to the vascular plant community and the tree stand structure of forests were also measured in $400 \mathrm{~m}^{2}$ plots. Islands were classified as young or old (Yls or Ols), according to their persistence age, which ranged from two to 108 years. Both island classes differed in their elevation but not in the proportion of low water phase. Only three out of nine tree species were dominant: Tessaria integrifolia and Croton urucurana (restricted to Yls and Ols, respectively), and Salix humboldtiana (distributed in both island classes). Alpha diversity was positively correlated with the age of the YIs and reach the highest value in the oldest island forest. Beta diversity was mainly due to processes of species replacement which differentiate floodplain forests. Gamma diversity reached 101 species, being the perennial herbs a clear majority. The stand structure and the complete floristic composition were significantly different between Yls and Ols, with three and seven indicator species of each island class, respectively. Considering integrative models of succession, our findings suggest that the biogeomorphic phase, recognised by the fluvial biogeomorphic model, prevailed in the whole range of island persistence ages. Therefore, it seems that the increase in forest diversity in a large river is restricted to spatial refugia defined by major hydrogeomorphic shifts.
\end{abstract}

Keywords: Middle Paraná River, Fluvial Biogeomorphic Succession, Vegetation Dynamics, Environmental Heterogeneity, Sand Bars, Hydrogeomorphic Dynamics munities of very variable diversity currently co-exist in similar hydro-sedimentological regimes (Kollmann et al. 1999, Neiff 2004, Latrubesse 2008, Hupp \& Osterkamp 2013). Therefore, the study of vegetation dynamics or plant successions needs to be addressed in the context of other temporal phenomena, e.g., landforms development (Gurnell et al. 2001).

An integrative conceptual model known as fluvial biogeomorphic succession has recently been proposed for fluvial and coastal systems (Corenblit et al. 2007). It com-
(1) Centro Científico Tecnológico CONICET Santa Fe, Predio CONICET “Dr. Alberto Cassano", Colectora Ruta Nacional 168 - Km. 0, Paraje El Pozo, 3000 Santa Fe (Argentina); (2) Facultad de Ingeniería y Ciencias Hídricas, Universidad Nacional del Litoral (FICH-UNL), Ciudad Universitaria UNL, Ruta Nacional 168 - Km 472.4, Santa Fe (Argentina), CC 217, 3000 Santa Fe (Argentina)

\section{@ Federico Brumnich (federicobn@gmail.com)}

Received: Jan 24, 2018 - Accepted: Apr 02, 2019

Citation: Brumnich F, Marchetti ZY, Pereira MS (2019). Changes in forest diversity over a chronosequence of fluvial islands. iForest 12: 306-316. - doi: 10.3832/ifor2737-012 [online 2019-06-06]

Communicated by: Matteo Garbarino prises four succession stages - geomorphic, pioneer, biogeomorphic and ecological - through which the purely physical, abiotic control over vegetation dynamics tends to decrease, while purely biotic control tends to increase (Corenblit et al. 2007). Although this scheme has mainly been applied in low discharge rivers, its predictions fit with the observations made in forests of large rivers (Jokinen et al. 1996, Wittmann et al. 2010).

The Paraná River forms the fourth largest hydrographic basin, in terms of its drainage area, only preceded in South America by the Amazon basin (Latrubesse 2008). The floodplain forests of the Middle Reach of the river are of particular interest as they participate in the consolidation of different types of bars and are helpful for mapping landforms (Pereira 2016). They provide elements of roughness that affect flood waves (Neiff 2004) as well as the habitat for many wildlife biotas (Bravo \& Sallenave 2003). All these functions are closely related to the floristic diversity of these forests, which is highly variable in spatio-temporal terms (Marchetti \& Aceñolaza 2012). However, there is little knowledge about their dynamics in relation to the fluvial context, not only in islands of the Middle Paraná River main channel but also in the 


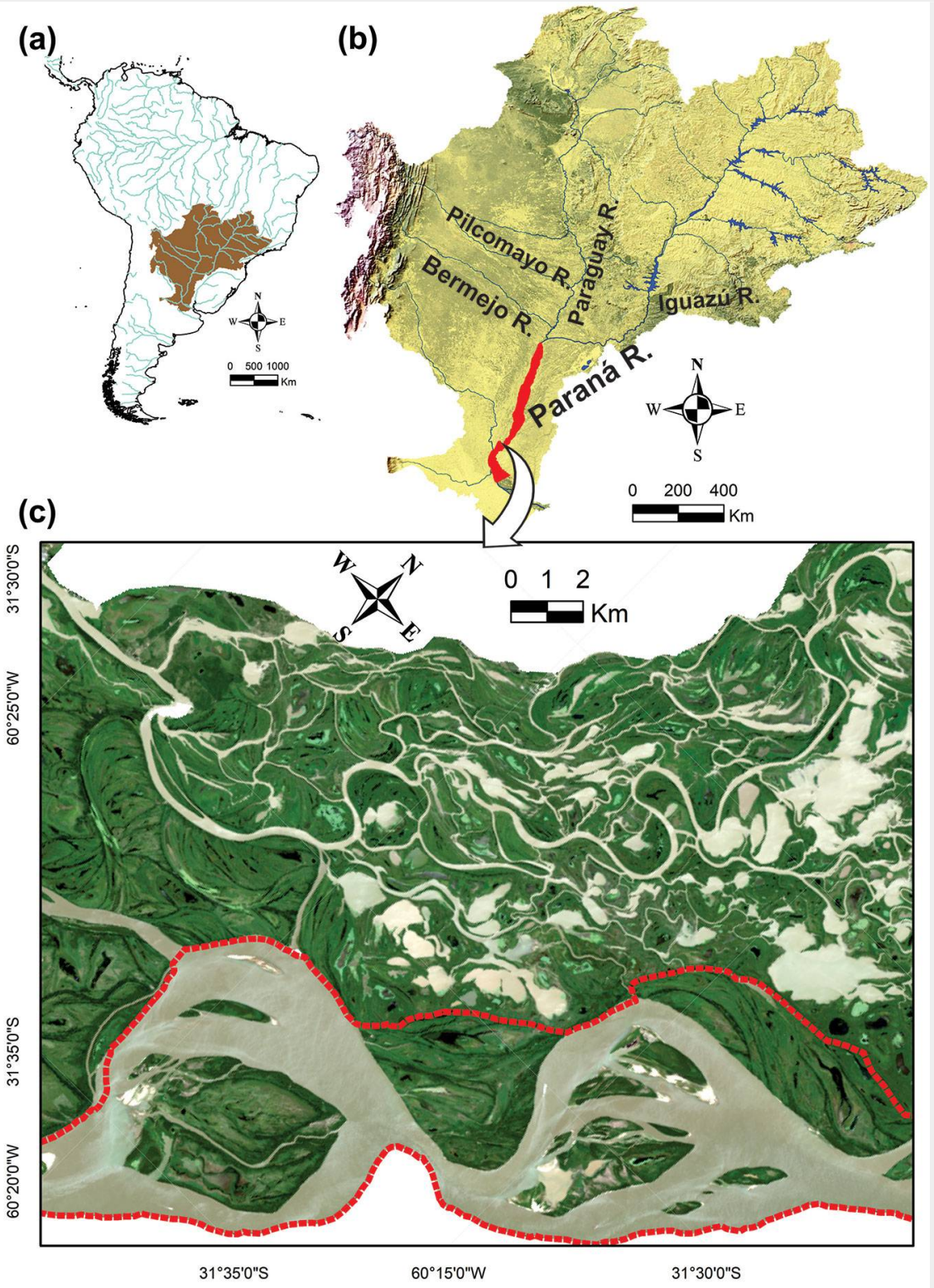

Fig. 1 - Study area. (a) Paraná River Basin in South America. (b) Middle Paraná River floodplain (area in red) and its main tributaries. (c) The studied islands, located within a reach of two enlargements, inside the geomorphic unit of "islands and bars of the main channel" (red dash lines), in the context of the Middle Paraná River floodplain.

whole floodplain. Only two studies have proposed schemes of successional pathways for the forests of the Middle Paraná River (Morello 1949, Lewis \& Franceschi 1979), in which the role of hydrogeomorphic dynamics in geomorphologic and hydro-sedimentologic terms has been barely considered, or even discussed so far, as the authors suggest.

In accordance with the above-mentioned context, the specific objectives of the present study were: (1) to determine the persistence age, current elevation and flood regime of the oldest bar of main channel islands; (2) to measure the forest diversity sensu lato (in terms of composition, abundance and tree stand structure) of the vascular plant community (woody and herbaceous species) placed in the abovementioned landforms. These objec- tives attempt to answer the following questions: (i) what is the relationship between the island persistence ages and the forest alpha diversity? (ii) is there any temporal trend in the shifts of composition or stand structure? (iii - as an integrative question) how synchronized are the major changes in the features of islands and forests?

\section{Methods}

\section{Study area}

The study area is delimited in a reach of the main channel of the Middle Paraná River floodplain (Fig. 1), which presents an anabranching channel pattern (Latrubesse 2008). This floodplain extends approximately from the city of Corrientes $\left(27^{\circ} 28^{\prime}\right.$ S) to Rosario ( $32^{\circ} 57^{\prime} \mathrm{S}$ ), Argentina (Fig. 1b); it has an area of about $18,000 \mathrm{~km}^{2}$, an average width of $30 \mathrm{~km}$, and a total length of the main channel of about $700 \mathrm{~km}$ (Pereira 2016). The climate is humid subtropical; average monthly temperatures range from 12 ${ }^{\circ} \mathrm{C}$ in July to $25^{\circ} \mathrm{C}$ in January, and rainfall accumulates $1027 \mathrm{~mm}$ a year, with a minimum of $29 \mathrm{~mm}$ in July and a maximum of 156 $\mathrm{mm}$ in March (data from the 1934-2014 series, at the Paraná station of INTA - Instituto Nacional de Tecnología Agropecuaria). The current modelling of the floodplain is due to an asymmetrical distribution of solid and water discharges from the Bermejo River and the Upper Paraná River, respectively, NW and NE of the basin (Amsler \& Drago 2009). The average annual discharge of water in the Middle Paraná River, at the beginning of the reach, is $17,000 \mathrm{~m}^{3} \mathrm{~s}^{-1}$. However, there were major discharge variations over the last century (Fig. 2), which determined: two "wet periods", 1904-36 and 1973-98, of high hydrological activity (i.e., a high frequency of floods greater than $30,000 \mathrm{~m}^{3} \mathrm{~s}^{-1}$ ), and another two "dry periods" $1937-72$ and 1999-2015, of low hydrological activity (Pereira 2016).

The group of 11 studied islands belongs to the geomorphic unit of "islands and bars of the main channel", which has a high turnover $(60 \%$ of its islands is less than 70 years old since its formation) and a large elevation variability that includes the highest sites in the whole Middle Paraná River floodplain (Pereira 2016). This group of islands is representative of the total number of islands in the main channel of the Middle Paraná, due to their great contrasts in terms of their age and because they were formed from central bars or from emerging bars linked to the migration of the thalweg (Pereira 2016). In addition, it is noteworthy to report that the main channel islands of the Middle reach have a relative low anthropogenic disturbance in contrast to the islands of the Upper reach and the Delta, which has been influenced by dams, deforestation, tree plantations and/or urbanization (Campos \& Souza 2002, Kandus \& Malvárez 2004). Thus, the islands of the present study have high research value, as they could serve as a "natural laboratory", both to study processes where human influence is not addressed (e.g., the present study) and for comparisons with other rivers of the Paraná basin with greater intensity of anthropic disturbances.

\section{Persistence age of the islands}

Through a multi-temporal analysis, the oldest bar of each island (i.e., the oldest current landform in an island) was delimited (Fig. 3). Then, the age of islands was estimated (in years) as the time between the sampling year (2015) and the year in which the oldest bar was colonised by plants. The persistence of each oldest bar, from its colonisation to the sampling, was verified (Sitzia et al. 2016). The six complementary sources of information used were: historical cartography (1847-1972) and 
Fig. 2 - Periods of contrasting discharge regimes of the Paraná River, from 1905 to the sampling year of this study. Geomorphologic changes of the studied islands across a temporal window are showed (sources from left to right: navigation chart, aerial photo mosaic, Landsat 2 MSS, Landsat 4 TM and Landsat $5 \mathrm{TM}$; for more details, see Tab. S1 in Supplementary material).

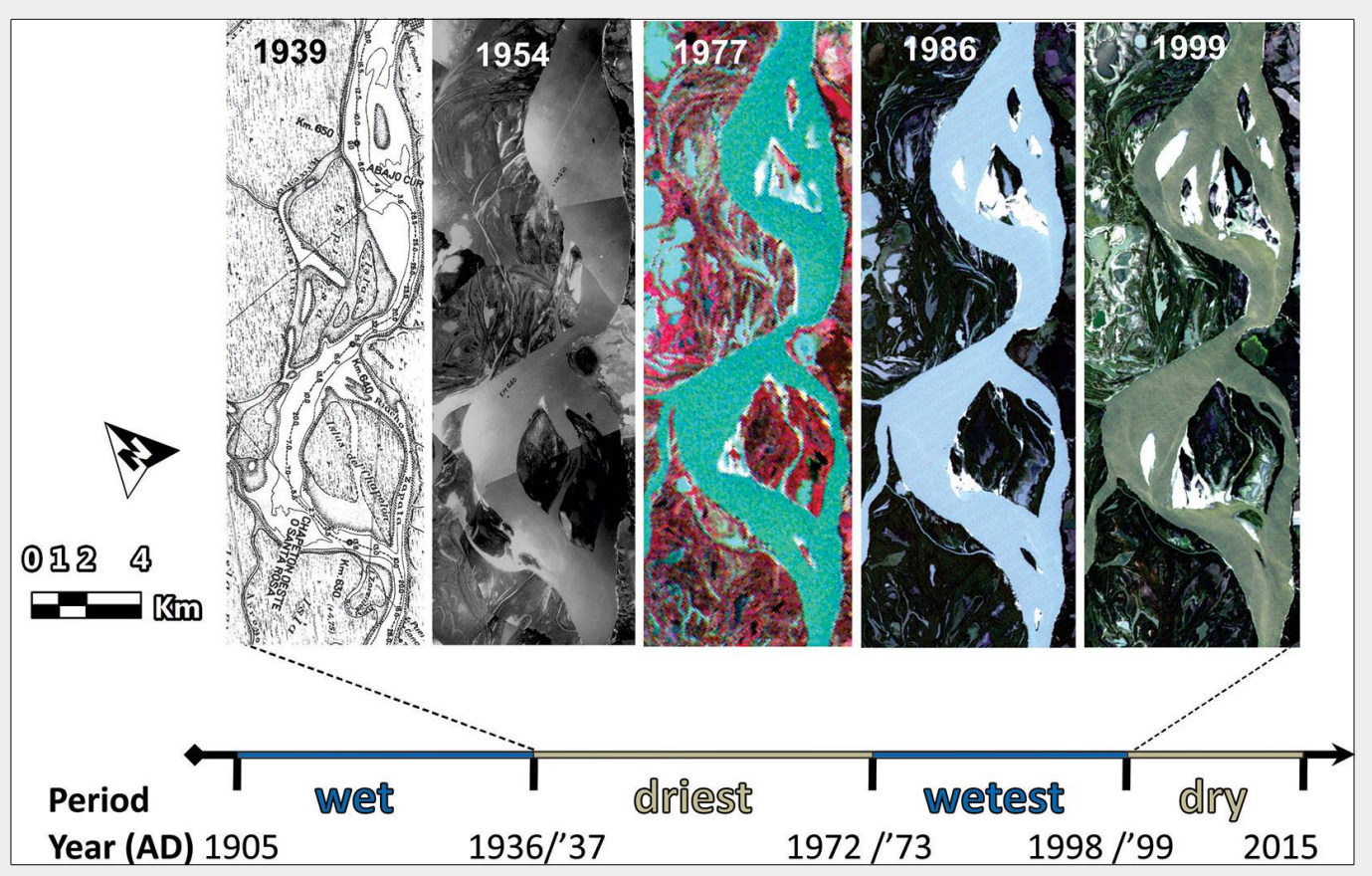

aerial photographs (1954-1984) surveyed mainly by State agencies from Argentina; Landsat MSS, TM, and OLI satellite imagery (1972-2015); and the DigitalGlobe ${ }^{\odot}$ (20022015) and Landsat/Copernicus (1984-2015) imagery mosaics in Google Earth Pro $^{\mathrm{TM}}$ and Google Earth Engine ${ }^{\mathrm{TM}}$ (see Tab. S1 in Supplementary materials for further details). Within the oldest bar area of each island, a set of potential sampling units were georeferenced (considering the current presence of forests, the accessibility to sample them and the maximum distance from signals of human influence). Then, only one of those units was randomly sampled in the field.

After its determination, persistence age has been treated as a continuous (chronological) explanatory variable, and classified into two discrete classes (according to the period in which the islands were formed): (i) old islands (Ols), formed before 1998, i.e., subject to the influence of at least one wet period, with high frequency of large discharges, and at least one extraordinary flood; (ii) young islands (YIs), formed during the dry period of 1999-2015 and consequently free from the influence of the Ols (in terms of both effective discharge and duration of floods).

\section{Elevation and flood regime}

The current elevation of each oldest bar was characterized by measuring ten points by means of geometric levelling, using the level of the water surface as a reference. The value of such reference was calculated as the sum of the hydrometric height of the river, on the day of sampling (measured at the gauge station of Paraná city), and the increase in the hydraulic slope. In turn, this increase was obtained from the route product (i.e., the distance from the sampling unit to the gauge station), and a $4.6 \mathrm{~cm} \mathrm{~km}^{-1}$ hydraulic slope (Toniolo 1999).
The series of daily water levels from 1907 to 2015 (>39,000 records) were obtained from the CIM database (Centro de Informaciones Meteorológicas at FICH-UNL).

The flood regime throughout the history of each oldest bar was analysed with an ad-hoc proxy: the "historic overflow level". It was obtained as the average between the minimum elevation (measured in the field) and a constant of two meters (above the zero measured at Paraná city gauge). This constant is the approximate elevation in which a bar is colonised by vegetation for the first time. The mentioned proxy was used because the sedimentation rate is not fully known yet. Thus, the precise reconstruction of the flood regime is not possible since vertical accretion tends to increase over time. The relationship between hydrometric levels and elevation was analysed with the Pulso software (Neiff \& Neiff 2003).

\section{Forest sampling}

Each oldest bar area was sampled with a single unit (Fig. 3), employing an equivalent sampling effort, seeking the homogeneity of the forest community and avoiding forests with signs of human-driven disturbances (e.g., high density of cattle manure or fire scars on trees). The methods corresponded to those classically used in vegetation studies (Müller-Dombois \& Ellenberg 1974). The sampling unit was a plot with an area of $20 \times 20 \mathrm{~m}$, where the following variables were measured: cover-abundance (CA) by species of all vascular plants; coverage and maximum height of each forest strata; diameter at breast height $(1.3 \mathrm{~m}$ above the ground, DBH) by species from the occurring trees, which also resulted in an absolute density per tree species. In high-density forests $\left(>5.000\right.$ trees $\left.\mathrm{ha}^{-1}\right)$, $\mathrm{DBH}$ and density were measured in subplots within the sampling unit (minimum of
$5 \mathrm{~m}^{2}$ - Franceschi et al. 1985). The frequency of all species was calculated based on the presence of each species in four subplots $(10 \times 10 \mathrm{~m})$ inside the plot, with the purpose of not overestimate the presence of rare species in the whole plot.

\section{Data analysis of forests}

The botanical determination was based on several botanical sources (additional information are reported in Appendix 1 Supplementary material). Systematics and nomenclature followed the criteria of the South America Southern Cone Flora list (Zuloaga \& Belgrano 2015); the same list was used to assign life-forms to the species, except for obligated aquatic herbs based on the list developed by Neiff (1986).

The floristic analyses were approached through the alpha, beta and gamma diversities (Gotelli \& Chao 2013) and multivariate techniques (McCune \& Grace 2002). Alpha diversity (based on the cover-abundance of each species) was calculated in effective numbers of species, or Hill numbers (considering three $q$-orders: $q=0, q=1$, and $q=2$, which indicate an increasing sensitivity to the relative importance of each species), and diversity profiles were made for the forest of each site (Hill 1973, Gotelli \& Chao 2013). Beta diversity was considered as the variation between forests that may be due to two phenomena: species replacement and dissimilarity by nesting (Baselga 2010). The Sørensen dissimilarity index modified by Baselga (2010) was used between pairs of forests (corresponding to pairs of islands in the chronological series of their ages), and between multiple forests (according to the $\mathrm{OI}$ and $\mathrm{YI}$ island classes). Gamma diversity was considered broadly as the species richness recorded in the forests of the main channel islands of the Middle Paraná River. Likewise, nonpara- 
metric richness estimators based on incidence were used to construct species accumulation curves (Gotelli \& Chao 2013).

Through an MRPP (Multi-Response Permutation Procedures), the differences between the island classes were evaluated considering three sets of forest attributes (tree stand structure, plant diversity, and total floristic composition). The distance matrices were constructed using the BrayCurtis index (recommended for quantitative data - McCune \& Grace 2002) and subjected to 4,999 permutations. The MRPP was complemented with a Species Indicator Analysis (SIA), which is used to contrast the performance of individual species through two or more groups of sampling units (Tichy \& Chytry 2006). The SIA calculates an indicator value (IV) for each species based on their cover-abundance and frequency. The statistical significance of the IV was assessed using a Montecarlo test with 4,999 permutations.

The statistical hypothesis tests were carried out by nonparametric methods: an exact Wilcoxon-Mann-Whitney test for the difference between medians in relation to the island classes, and Spearman's tests to prove the correlation between quantitative variables. All the hypothesis tests considered a level of significance $\alpha=0.05$. Statistical analyses were performed in $\mathrm{R}$ language (R Core Team 2017), using R Studio, with the packages: "coin" (Hothorn et al. 2006), iNEXT (Hsieh et al. 2016), "vegan" (Oksanen et al. 2018) and "betapart" (Baselga et al. 2018); further details are available in Appendix 2 (Supplementary material). The GUI software Pc-Ord (McCune \& Mefford 2011) was used in the MRPP and the SIA.

To interpret the changes in diversity along the chronology of islands as successional changes, the chronosequence approach, already used in floodplains (Kandus 1999, Cline \& McAllister 2012) was considered as accurate mainly due to two reasons. First, in temporal terms, this study was restricted to sites with a maximum of 100 years, which is considered an adequate temporal window (Walker et al. 2010). Secondly, in spatial terms, the sites correspond to only one type of landform (a sand bar), which belongs to a single geomorphic unit, thus the geomorphic complexity is simplified as much as possible (Pereira 2016).

\section{Results}

Persistence age of fluvial islands in the river context

Due to the persistence of plants on the oldest bar, the 11 islands were assigned ages of formation that cover a continuous timeline from two to 108 years (Fig. 3). These 11 islands, in turn, could be grouped into two discrete classes: five young islands ( $\mathrm{YI}$ ) and six old islands (OI - Fig. 3).

The Yls were between two and 16 years old and were formed from central bars or accretion bars downstream of pre-existing islands. Over the last decade, they have ex- perienced a dissimilar growth (from zero to double their original size) in different directions. Currently, these islands were composed of 3 landforms on average and 5 in total, mostly bars that were assembled to the oldest bar at different times and directions (by lateral, downstream or upstream accretion) and exceptionally separated by backswamps.

On the other hand, the Ols covered ages ranging from 31 to 108 years old and arose from central bars or accretion bars near the flanks of pre-existing islands. The growth of each OI has had high variability but it has been much less accentuated than in the YI over the last decade. In addition to age, the biggest difference between Ols and Yls is their current composition of landforms, e.g., levees, crevasse splay, and paleo-channels. The Ols gather 6 landforms on average and a total of 15 landforms (almost all of the landforms mapped for the entire geomorphic unit of the main channel of the Middle Paraná River).

The Ols surpassed the Yls significantly in the median of their elevation $(Z=8.68$; $\mathrm{P}=$ $\left.2.2 \cdot 10^{-6}\right)$. The elevations showed a significant linear correlation with the persistence age of islands $\left(r_{s}=0.73, P=4.4 \cdot 10^{-19}-\right.$ Fig. 4a).

Fig. 4b shows a limnigram for the last 108 years with the historic overflow levels of each one of the 11 sites. In the Ols, those levels range from 3.8 to $4.4 \mathrm{~m}$ above the zero of the Paraná gauge station (Fig. 4b). At such elevation and ages, all the islands
Fig. 3 - Island ages and location of the sampling units within the oldest bar area (Image source: Landsat OLI; date: 2014-01-15; water level at Paraná city gauge station: $2.43 \mathrm{~m}$ ). The island persistence ages are displayed both at the side of each oldest bar and in a timeline, which includes the sampling year.
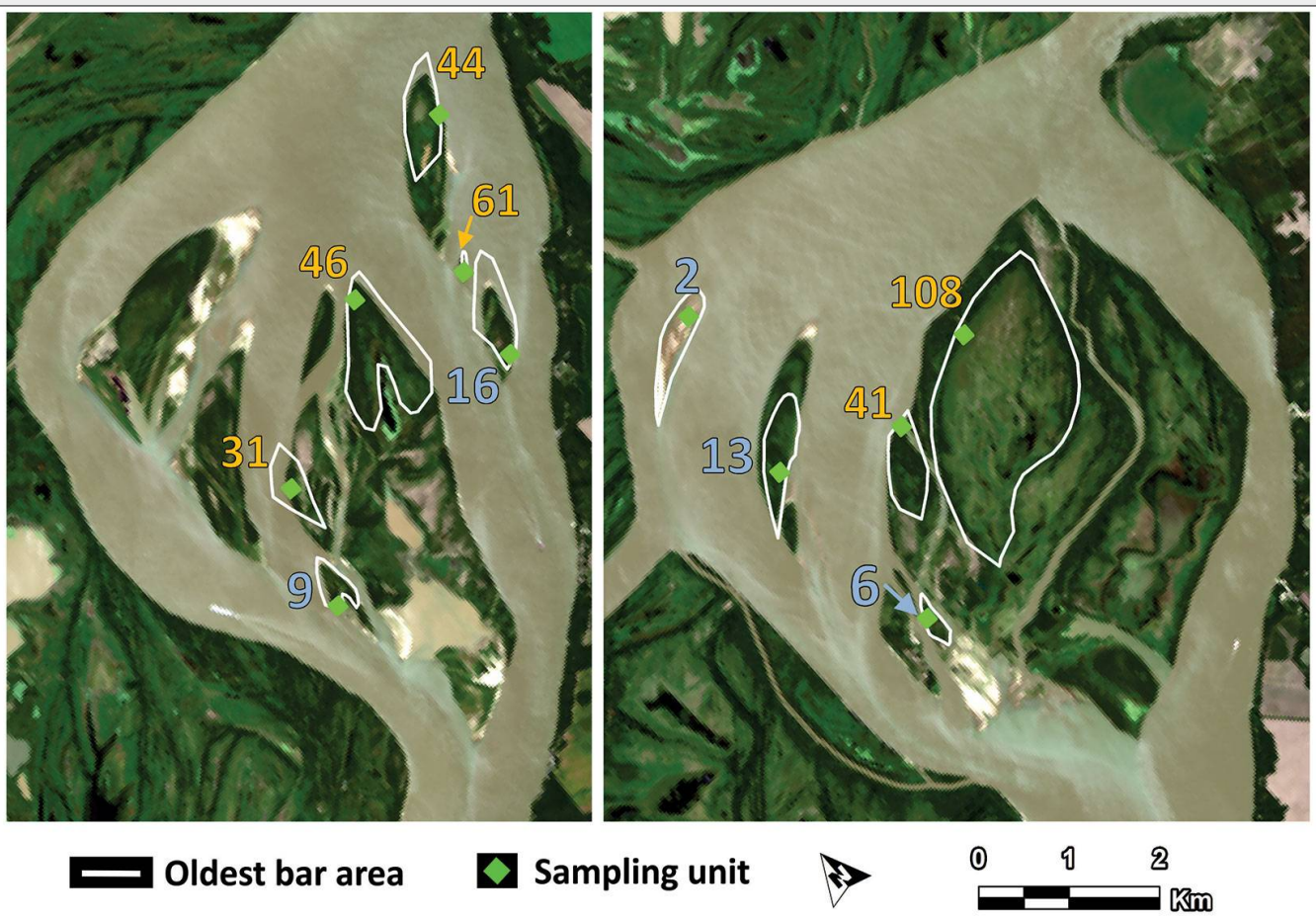

Oldest bar area Sampling unit

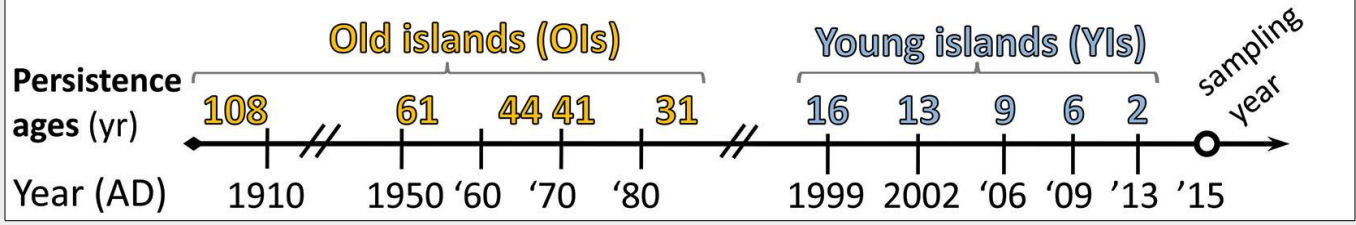


have been exposed to the extraordinary floods of the last wet period of 1973-1998, with durations of up to 15 months above 4 $\mathrm{m}$ (bankfull stage). Although in the Yls the levels of overflow were somewhat lower ( 3.3 to $3.7 \mathrm{~m}$ ), they have all appeared during the dry period from 1999 to the sampling year (Fig. 4b), for which they have only been modelled by ordinary floods.

The overflow levels of each site allowed obtaining some attributes that characterize in general terms the influence of flood and low water phases on each class of islands. The low water phase influenced the vast majority of island history with $72 \%$ in the Yls and $81 \%$ in the Ols. In contrast, the average duration of flood phase was more elevated in Yls than in Ols ( 85 vs. 76 days, respectively). However, the OI floods were of much greater intensity (higher flood peaks), with maximums exceeding the Yls up to 1 meter in terms of the water level.

\section{Diversity of the oldest bar forests in relation to the island features}

\section{Gamma-diversity, life-forms, and frequencies}

In the 11 forests studied, 101 species of vascular plants were recorded, being the majority concentrated in four orders and six families (a full checklist is given in Tab. S3 - Supplementary material). Perennial herbs $(38 \%$ of the species pool) were the best-represented way of plant life-forms, whereas the trees, climbers, annual herbs, and aquatic herbs reached less than $25 \%$ of the total biotic spectrum. In the chronological series, there was a slight tendency to decrease in the proportion of aquatic herbs and to increase in annuals herbs. Grouped according to persistence age ranges $(\mathrm{YI}$ and $\mathrm{OI})$, these differences were even more pronounced in annual and aquatic herbs (an $8 \%$ and 12\% gap in Yls and Ols, respectively), whereas the proportion of climbers and trees remained almost constant (a 1\% gap in both cases), and showed no linear trends in the chronological series (Fig. S1 in Supplementary material).

Regarding frequencies, only one species, Salix humboldtiana "Humboldt Willow", exceeded $80 \%$ while 71 species were rare since they did not reach $20 \%$. The vast majority of these species were restricted to YIs (29 out of 30 in total, e.g., the aquatic grass Louisiella elephantipes), or to Ols (27 out of 34 in total, e.g., the annual herb Ageratum conyzoides). Furthermore, the two classes of islands were characterized by the exclusivity of a dominant tree species: Tessaria integrifolia "River Alder" in YIs and Croton urucurana "Dragon's Blood" in Ols. On the other hand, the remaining 37 species were not only common (often more than 20\%) but they also became dominant in almost half of the cases, e.g., the perennial herbs Teucrium vesicarium and Steinchisma laxa, including the willows themselves.

The species richness extrapolation curves (a)

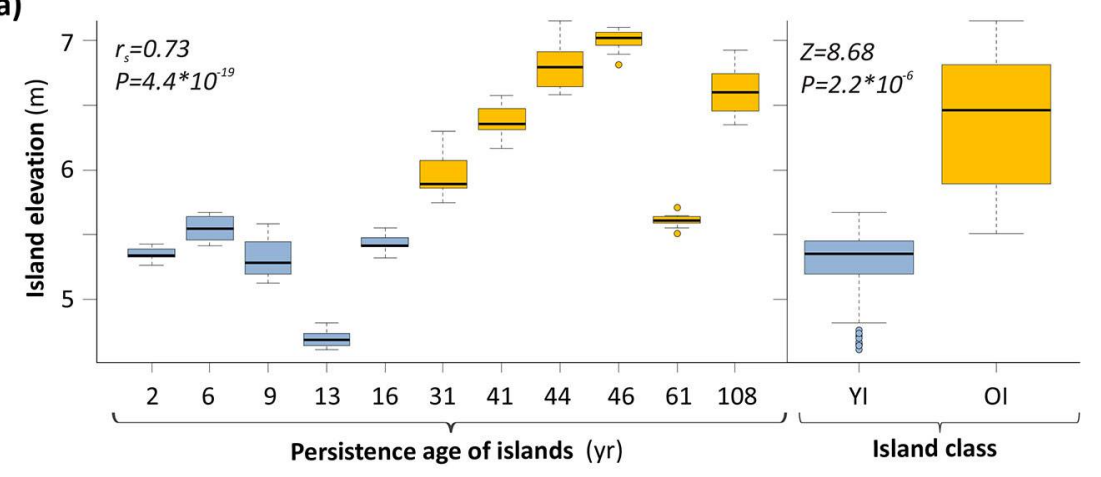

(b)

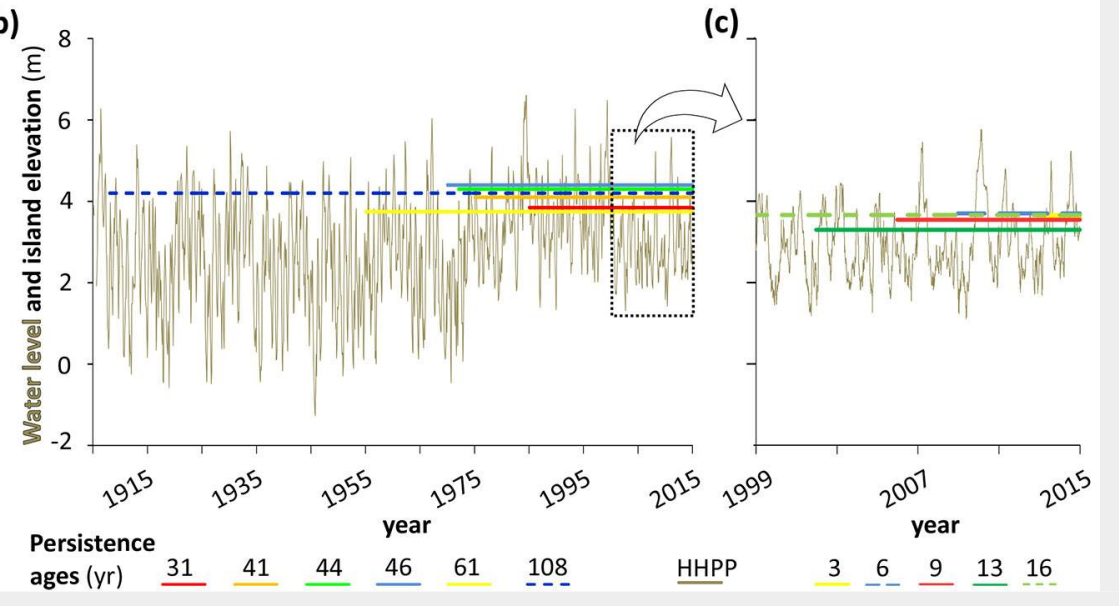

Fig. 4 - Islands elevation and water level fluctuations. (a) Box plots of the island elevation over the chronologic series of islands (left) and by island classes (right). (b). Water level variations of the Paraná River and the historic overflow level (see Methods) of the Old (left) and the Young Islands (right). The $y$-axis is relative to the hydrometer of the Paraná city gauge station.

in Yls and Ols showed two different behaviours (Fig. 5). The Yls curve seems to stabilize very far from its observed value, whereas the Ols observed value was very close to the stabilization of the curve.

\section{Alpha and beta diversity}

Alpha diversity presented differences in relation to the extreme ages of the islands

(Fig. 6a). As a whole, the forest of the oldest island is the most diverse since it is the only profile that is not intercepted by another in any q-order. On the contrary, the forest of the youngest island is the most unequal or with minimum equitability sensu lato, given the shape of its profile. In the remaining diversity profiles, the shape is similar between those of the Ols and dif-

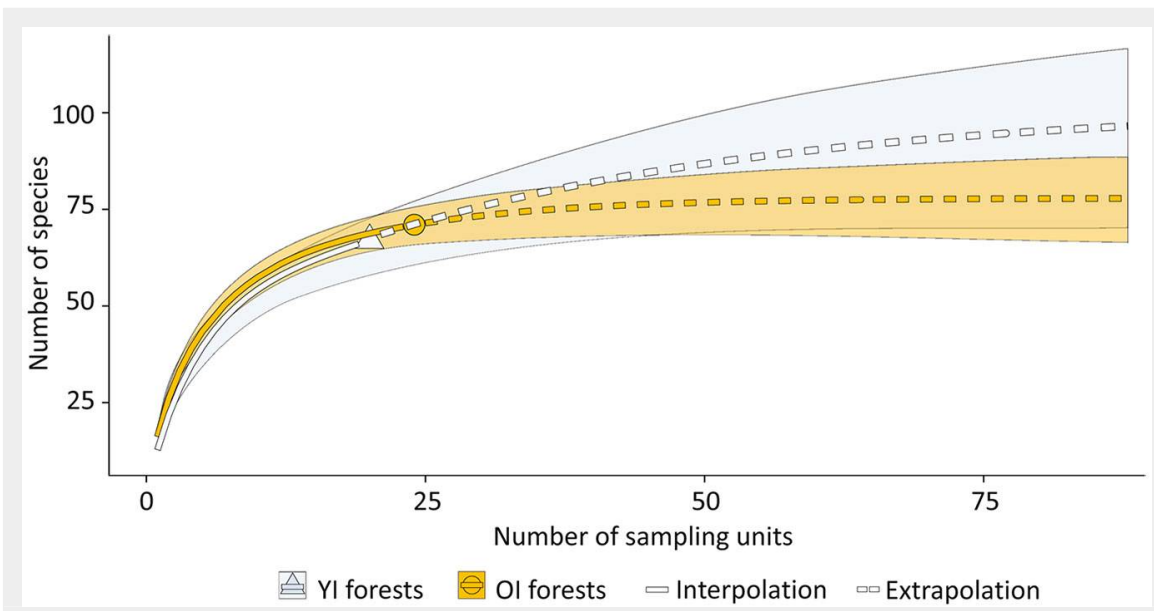

Fig. 5 - Species richness (alpha diversity, $q=0$ ) extrapolation curves for the Old (OI) and the Young Islands ( $\mathrm{YI})$. The shadow area represents a $95 \%$ confidence interval based on 999 permutations for each curve. 

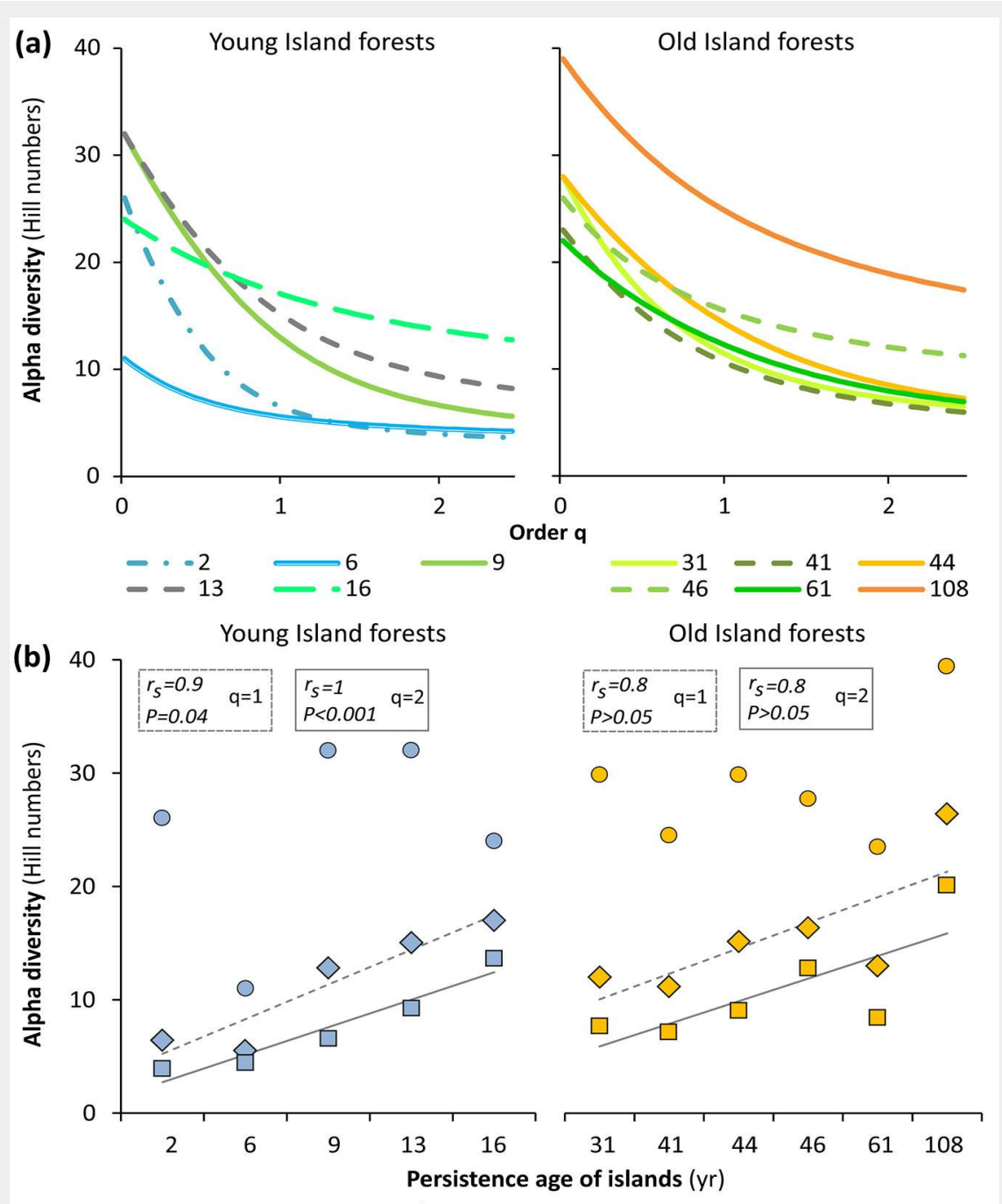

OSpecies richness $(q=0) \quad \diamond$ Common species ( $q=1) \quad \square$ Dominant species ( $q=2)$

Fig. 6 - Alpha diversity of forests. (a) Alpha diversity profiles of Young (left) and Old Island forests (right); the value of the q-order indicates an increasing sensitivity to the relative importance of each species. (b) Alpha diversity over the chronologic series of Young and Old Island forests; cases with a strong linear correlation $\left(r_{s}>0.7\right)$ are highlighted.

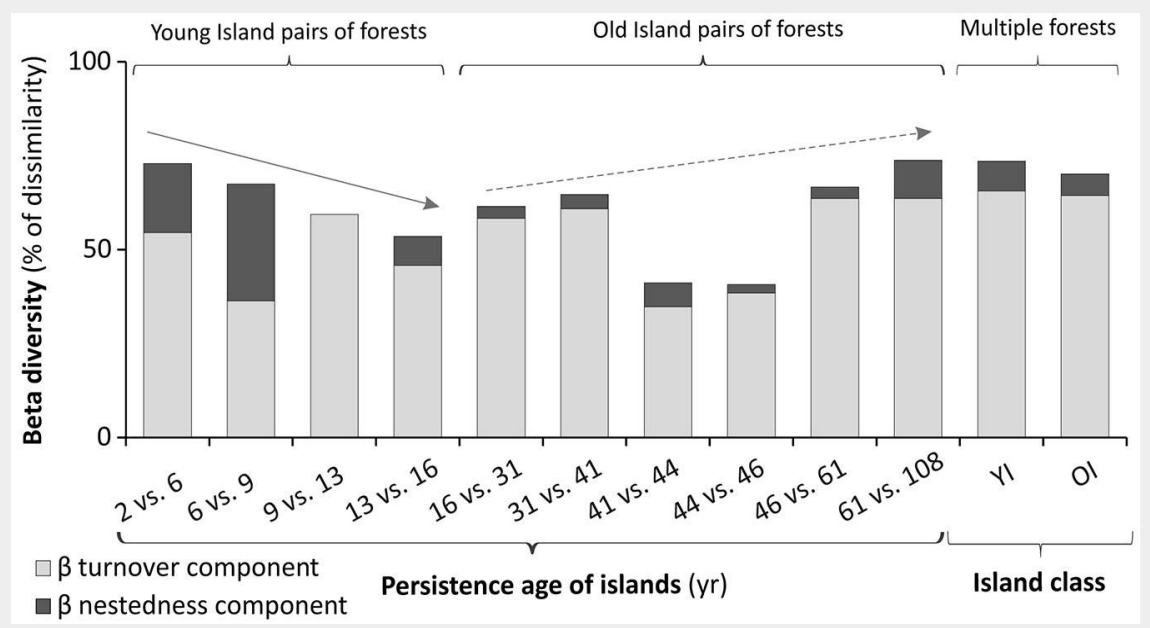

Fig. 7 - Beta diversity of forests. On the left side: beta diversity between pairs of forests over the chronologic series of islands; arrows highlight trends (see text). On the right side: beta diversity in multiple forests, corresponding to Young and Old Island classes ( $\mathrm{YI}$ and $\mathrm{OI}$ ). fers between those of the Yls, which could indicate greater and lesser stability, respectively.

Regarding temporal trends, the correlations between the chronological series of the islands and the alpha diversity were extremely weak for the three q-orders $\left(r_{\mathrm{s}} \leq\right.$ $0.4)$. However, the Yls ages did show a positive, strong and significant correlation, both with the common species number $(q$ $\left.=1, r_{s}=0.9, P=0.04\right)$ and the dominant species number $\left(q=2, r_{s}=1, P<0.01\right)$. The Ols ages also revealed a positive and strong correlation with the same two q-orders of diversity $(q=1$ and $q=2)$, but only at the sample level $\left(r_{s}=0.8, P>0.05\right.$, in both cases - Fig. 6b).

The beta diversity analysis between pairs of forests (island) showed two relatively clear patterns. The dissimilarity tends to decrease steadily in the YIs and to increase from the passage of young to old islands (16 vs. 31 years old) to the oldest which were surveyed (Fig. 7). The scarce beta diversity value between forests of old islands with close ages ( 41 vs. 44 and 44 vs. 46 years old) attenuates the latter tendency towards an increase in dissimilarity. The beta diversity analysis among multiple forests (Fig. 7) showed the greatest changes in the five $\mathrm{Yl}$ forests, in relation to the six Ol forests. In general, the species replacement component predominated in both analyses, which indicated greater importance of changes in species composition over changes in richness (dissimilarity component by nesting) in determining beta diversity.

\section{Forest and tree stand structure}

Forests generally have three well-defined strata with high variability in the maximum heights and coverages of each stratum, both in the series of islands and in the $\mathrm{YI}$ and Ol classes (Tab. 1). The dominant/codominant species was constant only for the YI canopy (willows and/or alders). Meanwhile, there were dominant/codominant and constant species in the OI canopy (willows), the Ol understory (Dragon's Blood), and the OI herbaceous layer (S. laxa and $T$. vesicarium). Only three out of nine tree species had large and common populations: C. urucurana, T. integrifolia, and $S$. humboldtiana, with densities greater than 75 trees ha ${ }^{-1}$ and more than $30 \%$ of frequency.

The $\mathrm{YI}$ average diameter (DBH) and the maximum height of willows and alders seemed to increase steadily in the chronological series (Tab. 2). In contrast, none of the OI 4 structural variables (density, C-A, maximum height, and mean DBH) of $S$. humboldtiana and C. urucurana showed a clear tendency (Tab. 2).

Regarding the age structure, which was estimated from the distribution of $\mathrm{DBH}$ (470 measured trees), both $T$. integrifolia in $\mathrm{YI}$ and C. urucurana in OI, concentrated most of their individuals in DBH of up to 5 or $10 \mathrm{~cm}$, respectively; consequently, their 
populations were likely to be quite young (Fig. 8). On the other hand, the populations of S. humboldtiana differed according to the type of island: it presented a skewed distribution to $\mathrm{YI}$ young populations, while the OI distribution of DBH approaches a normal distribution (Fig. 8).

\section{Forest multiple attributes and indicator species}

The variables presented above were analysed jointly using multivariate techniques.

The results of the Multi-Response Permutation Procedures (MRPP) showed that the differences in the $\mathrm{YI}$ and $\mathrm{OI}$ tree structure ( $\mathrm{DBH}$, density, and height) were significant $(A=0.14, P=0.01)$. Likewise, the $C-A$ of the 101 species also varied significantly from these two island classes $(A=0.09, P<$ 0.01). On the other hand, the MRPP that evaluated the variation in alpha diversity and proportion of life-forms did not show significant differences between both island classes, showing a very low intra-group homogeneity $(A=0.02, P=0.17)$.

The Species Indicator Analysis (SIA) provided the maximum and significant indicator value (IV $=1, P=0.003$ ) for $T$. integrifolia and C.urucurana, the two tree species restricted, respectively, to Yls and Ols. Likewise, another 12 species (mostly herbaceous) had a relatively high IV (from 0.6 to 0.7 ) and also a $P<0.10$, which is noteworthy, given the fact that the number of sampling units may have masked their real importance. Of these 12 species, only 2 were exclusive to Yls (Eragrostis hypnoides and Hymenachne aplexicaule), while 5 were restricted to Ols (Cantinoa mutabilis, Nectandra angustifolia, Setaria parviflora, Cyclospermum leptophyllum and Sphagneticola brachycarpa); the remaining 5 were present in all the islands ( $T$. vesicarium, Mikania cordifolia, Cyperus eragrostis, Phyla nodiflora var. reptans and Commelina diffusa). The complete species list of the SIA is given in Tabl. S3 and Tab. S4 (Supplementary material).

As a complement of the abovementioned results, Fig. S2 and Fig. S3 in Supplemen-
Tab. 1 - Forest structure variables (minima and maxima values) in Young and Old Islands forests. (*): species marked with an asterisk were only dominant in two forests (while the remaining species were dominant in at least four forests).

\begin{tabular}{|c|c|c|c|c|c|c|}
\hline \multirow{2}{*}{$\begin{array}{l}\text { Forest } \\
\text { strata }\end{array}$} & \multicolumn{3}{|c|}{ Young Islands (2-16 yrs) } & \multicolumn{3}{|c|}{ Old Islands (31-108 yrs) } \\
\hline & $\begin{array}{l}\text { Height } \\
(\mathrm{m})\end{array}$ & $\begin{array}{c}\text { Cover } \\
(\%)\end{array}$ & $\begin{array}{l}\text { Dominant } \\
\text { species }\end{array}$ & $\begin{array}{l}\text { Height } \\
(\mathrm{m})\end{array}$ & $\begin{array}{c}\text { Cover } \\
(\%)\end{array}$ & $\begin{array}{l}\text { Dominant } \\
\text { species }\end{array}$ \\
\hline Canopy & $4-10$ & $10-90$ & $\begin{array}{l}\text { Salix humboldtiana, } \\
\text { Tessaria integrifolia }\end{array}$ & $5-16$ & $5-70$ & Salix humboldtiana \\
\hline Understory & $2-3$ & $0-40$ & Ludwigia elegans* & 4 & $5-60$ & Croton urucurana \\
\hline Herbaceous & $0-1$ & $0-90$ & - & $0.5-2$ & $5-90$ & $\begin{array}{l}\text { Steinchisma laxa*, } \\
\text { Teucrium vesicariun }\end{array}$ \\
\hline
\end{tabular}

Tab. 2 - Structure of the main tree populations in Young and Old island forests. Each range values is shown in chronological order; cases where the minima and maxima of a variable match the extreme age of an island, are indicated with an arrow.

\begin{tabular}{|c|c|c|c|}
\hline Tree populations & Variables & $\begin{array}{l}\text { Young Island } \\
\text { (2-16 yrs) }\end{array}$ & $\begin{array}{c}\text { Old Island } \\
(31-108 \text { yrs })\end{array}$ \\
\hline \multirow{4}{*}{$\begin{array}{l}\text { Salix humboldtiana } \\
\text { "Humboldt willow" }\end{array}$} & Density (trees ha-1) & $24000 \Rightarrow 600$ & $1600-200$ \\
\hline & Mean DBH $(\mathrm{cm})$ & $2.3 \Rightarrow 18$ & $15.7-37$ \\
\hline & Maximum height $(\mathrm{m})$ & $4 \Rightarrow 10$ & $5-16$ \\
\hline & Cover-Abundance (\%) & $40-15$ & $5-60$ \\
\hline \multirow{4}{*}{$\begin{array}{l}\text { Tessaria integrifolia } \\
\text { "River alder" }\end{array}$} & Density (trees ha ${ }^{-1}$ ) & $60000 \Rightarrow 500$ & - \\
\hline & Mean DBH $(\mathrm{cm})$ & $2.6-11.4$ & - \\
\hline & Maximum height $(\mathrm{m})$ & $4 \Rightarrow 10$ & - \\
\hline & Cover-Abundance (\%) & $40-15$ & - \\
\hline \multirow{4}{*}{$\begin{array}{l}\text { Croton urucurana } \\
\text { "Dragon's blood" }\end{array}$} & Density (trees ha-1) & - & $300-800$ \\
\hline & Mean DBH (cm) & - & $7.5-14.2$ \\
\hline & Maximum height $(\mathrm{m})$ & - & $4-6$ \\
\hline & Cover-Abundance (\%) & - & $10-73$ \\
\hline
\end{tabular}

tary material report field photos and summarize remarkable features of the oldest bar forests.

to, at least, two variables: persistence age and elevation of the landform, both extremely useful to evaluate how the disturbance regime (e.g., waterlogging) can distort the autogenic successional pathways of vegetation (Kandus 1999, Pickett et al. 2013).

The significant differences in the current

Linking forest diversity to island

dynamics

In floodplains, hydrogeomorphic dynamics have been considered as the main driver of changes in forest diversity over time (Corenblit et al. 2007, Hupp \& Osterkamp 2013). These dynamics are related elevation between the island classes are explained by the contrasting effective discharge during the wet and dry periods in which the islands were formed. In turn, these periods are strongly linked to hy-
Fig. 8 - Diameter classes of the three dominant arboreal populations. The diameter at breast height ( $\mathrm{DBH}$ ) is ordered according to the relative density of each population.

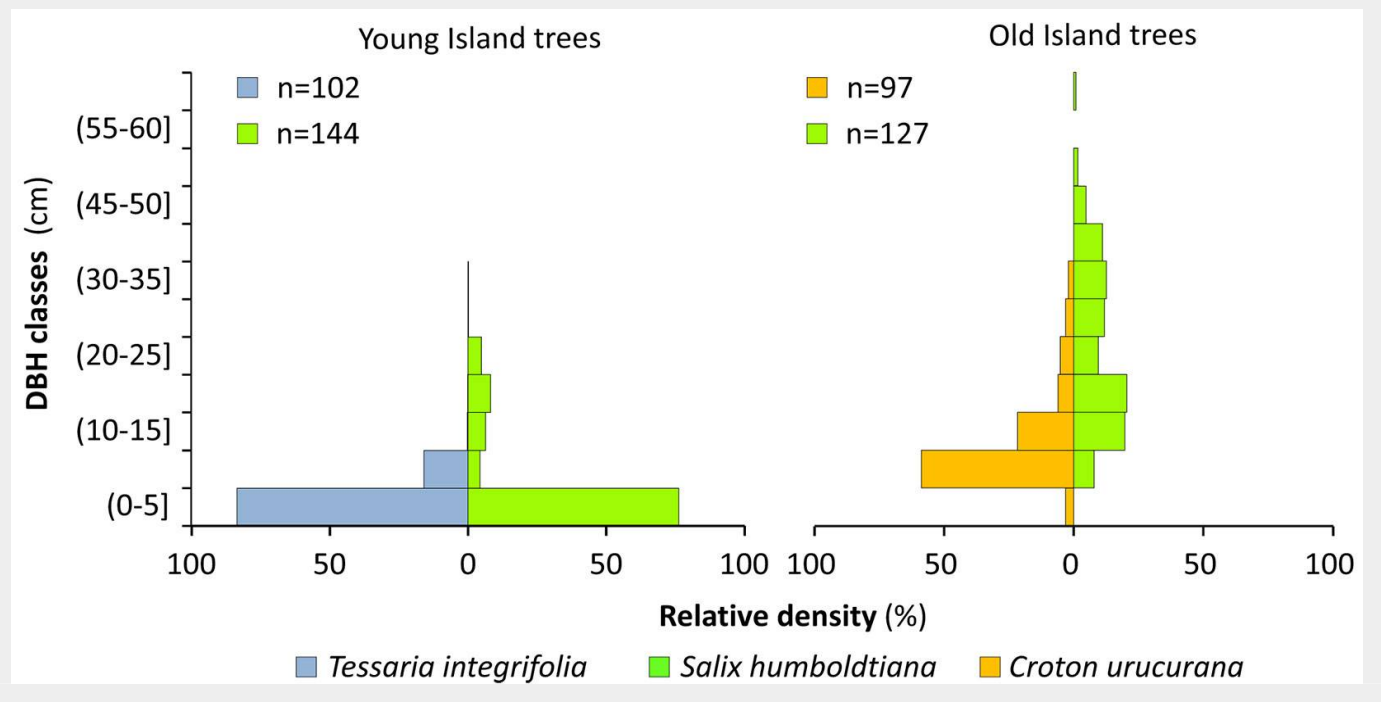


draulics and the horizontal and vertical ac cretion of the sand bars occurred in this particular stretch of the Middle Parana River (Pereira 2016). In spite of these elevation differences, the proportion of the low water phase was predominant among all the islands. Consequently, the impact of such phase on forest diversity was similar, since it limits the recruitment of seedlings but favours the radial growth of trees, and the development of herbs and climbers (Casco et al. 2005, Parolin et al. 2010, Wittmann et al. 2010, Marchetti \& Aceñolaza 2012).

On the other hand, it is in the high water phase, or flood stage, where sedimentation events are concentrated, enabling vertical accretion. Therefore, this phase is relevant, since sedimentation rates have been negatively correlated with the age of flood plain forests, based on the decreasing tendency in the density of trees over the en tire successional sequence, favouring ac cretion (Wittmann et al. 2010). In this sense, a winter flood of the Paraná River contributed up to $60 \mathrm{~cm}$ thick of fine sediments (silt and clay) in young alder forests, while up to $5 \mathrm{~cm}$ were recorded in mature willow forests; paradoxically, these forests clearly differed in their diversity but not so much in their former elevation (Marchett et al., unpublished). In a large summe flood $\left(>30,000 \mathrm{~m}^{3} \mathrm{~s}^{-1}\right)$, the sedimentation has reached a layer greater than 1 mete (Ramonell et al. 2011), which shows the rapid changes happened in the main chan nel islands.

Our results show that forests increased their alpha diversity over time, as it has been reported in other large river flood plains (Campbell et al. 1992, Worbes et al. 1992, Wittmann et al. 2010). More specifically, the change in floristic composition along the chronological series of islands, ranging from forests with Tessaria integrifolia and 29 other species, restricted to young islands (YIs), to forests with Croton urucurana and other 33 species limited to Old Islands (OIs), had not been recorded in the literature (Lewis \& Franceschi 1979 Neiff 2004). This noteworthy floristic change between the two island classe was also supported and reflected by the behaviour of beta diversity along the island chronology. In this sense, a similar "reflec tion" between the floristic and geomorphological patterns has been reported in the Tagliamento River in Italy (Kollmann et al. 1999).

In YI forests, the composition of vascular plants is unstable since a large proportion of aquatic life-forms appeared as tourist species (Halffter \& Moreno 2005), with a tendency to decrease over time along with beta diversity. On the other hand, YI tree species are not only constant but also their homogeneity in diameter classes indicates that the age of forests can be associated with the age of islands formed in dry periods. This association was in fact supported by dendrochronological approaches that validated what was observed by cartographic sources for islands which are less than 20 years old (Morello 1949, Brumnich et al. 2016). In this sense, Tessaria integrifolia has been assigned a maximum age of 20 years old (Neiff \& Reboratti 1989), which is consistent with our results as this tree species was restricted to islands up to 16 years old.

Contrary to Yls, the floristic composition in the Ol forests is more stable and the dominant tree species in the forest canopy presents greater heterogeneity in diametric classes. This heterogeneity could indicate a discrepancy, or delay, between the age of formation of such islands and the age of the dominant species of the forest canopy (Salix humboldtiana). In this sense, S. humboldtiana has been referred as the arboreal species with the greatest niche amplitude, occurring in very contrasting forests with very different hydrogeomorphic drivers (Liotta 2001, Neiff 2004, Marchetti \& Aceñolaza 2012). Although a maximum age of 16 to 20 years old has been determined for $S$. humboldtiana in the Central Amazon River floodplain (Worbes et al. 1992, De Oliveira \& Piedade 2002), we recorded forests of Salix humboldtiana in older sites, which has persisted after extraordinary floods. This fact, suggests that $S$. humboldtiana could survive more than 20 years in the floodplain of the Middle Paraná River. Similar patterns of delay between ages of islands and floodplain forests have been found in other large rivers. For islands of the upper reaches of the Amazon River (namely, Peru), Jokinen et al. (1996) detected a delay between the age of the island oldest site and the successional stage of forests. The authors claimed that the isolation of the erosive processes, given by the distance of the island to the active channel, determined forests of greater complexity (which does not necessarily mean a greater age of the area colonised by such forests on the island). These sectors, involving a low influence of hydrogeomorphic disturbances, act as spatial refugia which seems to be a common feature of very contrasting river systems. For example, the greater diversity of tree species in the Tokachi River (Japan) was associated with stable sites in hydrogeomorphic terms (Shin \& Nakamura 2005); the inactive channels of the Sacramento River (USA) are a refuge for their pioneer species during periods of high stress (Stella et al. 2011). Thus, both our results and the available literature suggest that the hydrogeomorphic dynamics would tend to mix, progressively, the attributes of mature and young forests in sites directly connected to the main routes of water and sediments.

\section{Succession in island forests of the Middle Paraná River}

So far, there are only two studies that have addressed the primary succession sensu lato in sand bars of the main channel of the Middle Paraná River (Morello 1949, Lewis \& Franceschi 1979). In his study, Morello (1949) reported that the first woody plant colonising the bar is a tall bush, Baccharis salicifolia, preceding willow and alder forests, and that all subsequent successional pathways converge in the "white forest", an association of 4 tree species. For their part, Lewis \& Franceschi (1979) pointed out that although the vegetation units which transform the bars into islands are made of pure alders or mixed with willows, the pathways do not necessarily converge in a single community, the most consistent proposal being the one that culminates in the Forestum insularis, a forest in some way similar to the "white forest". Both studies are to some extent related to the "classical" approach of succession, in which the analysis is restricted almost exclusively to changes in plant diversity, implying that there is little certainty about the influence of hydrogeomorphic dynamics on the consequent successional pathways. Thus, the aspects relating to age and elevation of the landforms remain unanswered, all of which is basic knowledge to understand the role of vegetation-landform feedback in succession.

Considering this feedback, the fluvial biogeomorphic succession approach (Corenblit et al. 2007) identifies, through four different phases, the relative importance of physical and biotic compartments in such plant diversity changes. From this approach and considering the studies mentioned above and the relevant literature, our results show features of two successional phases: (i) the "pioneer phase" (defined by a predominance of abiotic filters and an incipient biotic influence); and (ii) the "biogeomorphic phase" (characterized by a shared control of the physical and biotic filters and a maximum feedback between both).

In the first place, a minimal stabilization of the sand bars made it a suitable habitat for the woody species colonisation, and could be facilitated by strictly aquatic species. The set of aquatic species found as companions in the recent islands of our study (tourist species in the forests) is consistent with marshy and submerged hydrophytes reported as the first plant colonizers of the bars (Morello 1949, Eskuche 2004). On the other hand, Lewis \& Franceschi (1979) describe them as rare and despicable pioneer species. Contrasting both contributions with our results, this biogeomorphic structure (i.e., bars and hydrophytes) could be interpreted as an ephemeral "pioneer phase", which contributes, only under conditions of low fluctuation of the water level (disturbances of low intensity, duration, and recurrence), to the recruitment of the ecosystem engineers of the following phase: willows and alders. In this sense, the germination of willows would be the key process that marks the transition from the pioneer phase to biogeomorphic phase. It is worth adding that 
there is no agreement in the literature on whether the flooded soil constraints this process of germination (Neiff 2004) or not (Oliveira-Wittmann et al. 2007).

All the floodplain forests discussed in this study would be part of a "biogeomorphic phase", considering the 3 dominant tree species could be associated with early successional stages, e.g., in terms of biological traits such as the low density of wood (Worbes et al. 1992). Also, these 3 species are tolerant to a great intensity of hydrogeomorphic disturbances. On the one hand, it can be observed that in the Young Islands, willows and alders are the engineer species acting as a trap of fine sediments and associated nutrients, favouring the recruitment of a large variety of vegetation life-forms (Lewis \& Franceschi 1979). In the Old Islands, the codominant of the willow, i.e., Croton urucurana, is a diagnostic species of an Association sensu stricto labelled as disturbance-recovering (Eskuche 2004). Furthermore, $C$. urucurana was dominant in a forest located on a 44-year-old island, in which a large crevasse splay was detected (Fig. $\mathrm{S}_{3}$ in Supplementary material). Such landform is an indicator of a great disturbance since the granulometry of the original levee, and, presumably, its floristic composition is modified in its genesis.

In our study, and contrary to previous contributions (Morello 1949, Lewis \& Franceschi 1979), a plurispecific forest on levees was not detected. This biogeomorphic structure (i.e., levee and plurispecific forest) could be seen as an "ecological phase" within the fluvial biogeomorphic succession, where biotic interactions (e.g., competition and mutualism) are the main driver of vegetation features because of a spatial disconnection from the hydrogeomorphic processes of disturbance (Corenblit et al. 2007). Precisely, we understand that the distance of the oldest bar areas to the anabranches of the main channel (in ten islands such distance was less than 50 $\mathrm{m})$, represented a strong limitation in the recruitment of late successional species (e.g., with traits such as high density of wood - Worbes et al. 1992). Conversely, the spatial disconnection of the disturbance has been related to the location of forests with the maximum richness of tree species in large floodplains (Jokinen et al. 1996, Neiff 2004, Wittmann et al. 2010). In the Middle Paraná River floodplain more specifically, such forests have been surveyed in geomorphic units with a very low disturbance rates such as point bars of the San Javier River, internal levees of the large main channel islands or old point bar of the Colastiné River (Franceschi et al. 1985, Fritschy 2004, Neiff 2004, Marchetti \& Aceñolaza 2012, Marchetti et al. 2013). Therefore, it seems that the increase in floodplain forest diversity in a large river is linked to spatial refugia defined by the fluvial hydrogeomorphic dynamics.

iForest 12: 306-316

\section{Conclusions}

In this study, we provide some valuable insights for future research on the temporal trends of forests and islands in a large river. Some attributes of forest diversity (floristic composition and stand structure) showed significant changes synchronized to the change from the young to the old island classes. Hence, these classes could be seen as major successional shifts in both vegetation and landforms, involved mostly in a biogeomorphic phase. This fact highlights the need to combine the potentialities of different disciplines in the study of fluvial systems, given the fact that changes occur simultaneously in hydrogeomorphic and ecological levels. In addition, it would be very useful to validate the cartographic approximations on the island ages with methods that provide greater resolution on the age of the floodplain forests, e.g., by means of dendrochronological approaches. Accordingly, the relevance of models (such as the fluvial biogeomorphic succession), and approaches (such as the dendrochronology), lies in their potential contribution to ecological models that complement the hydro-geomorphological ones, in the task of unravelling the entire dynamics of large river floodplains.

\section{List of abbreviations}

(C-A): cover-abundance; (DBH): diameter at breast height (1.3 $\mathrm{m}$ above the ground); (OI): Old Islands; (YI): Young Islands; (IV): Indicator Value in the Species Indicator Analysis; (MRPP): Multi-response Permutation Procedures; $(P)$ : $p$-value in statistical hypothesis tests; $(q)$ : a key parameter ("order") in an effective number of species ("Hill numbers"); $\left(r_{s}\right)$ : Spearman's correlation coefficient of the Spearman correlation test; (SIA): Species Indicator Analysis; (Z): standardized statistic of the exact Wilcoxon-Mann-Whitney test.

\section{Acknowledgements}

We thank Carlos G. Ramonell for his advice, particularly at the beginning of this study. Also, we thank Mauro Galiano (FICHUNL, Santa Fe, Argentina) for his helpful assistance in the elevation survey. We are very grateful with the three anonymous reviewers, whose comments enhanced the quality of our original work. This study was carried out through funds provided by project PICT 2014-3139 from the ANPCyT (Agencia Nacional de Promoción Científica y Tecnológica). FB has a doctoral scholarship from the CONICET (Consejo Nacional de Investigaciones Científicas y Técnicas).

\section{References}

Amsler ML, Drago EC (2009). A review of the suspended sediment budget at the confluence of the Paraná and Paraguay Rivers. Hydrological Processes 23: 3230-3235. - doi: 10.1002/hyp. 7390

Baselga A (2010). Partitioning the turnover and nestedness components of beta diversity. Global Ecology and Biogeography 19 (1): 134-
143. - doi: 10.1111/j.1466-8238.2009.00490.x

Baselga A, Orme CDL, Villeger S, De Bortoli J, Leprieur F (2018). betapart: partitioning beta diversity into turnover and nestedness components. $R$ package version 1.5.1. [online] URL: http://CRAN.R-project.org/package=betapart Bravo SP, Sallenave A (2003). Foraging behavior and activity patterns of Alouatta caraya in the northeastern Argentinean flooded forest. International Journal of Primatology 24 (4): 825846. - doi: 10.1023/A:1024680806342

Brumnich F, Morales MS, Marchetti ZY, Ramonell CG (2016). Dendrocronología en el río Paraná Medio: explorando su potencialidad para comprender la dinámica de un gran sistema fluvial [Dendrochronology in the Middle Paraná River: exploring its potential to understand the dynamics of a large fluvial system]. In: Proceedings of the workshop "VI Reunión Binacional de Ecología”. Puerto Iguazú (Argentina), 18-22 Sep 2016. Asociación Argentina de Ecología and Asociación de Ecología de Chile, Puerto Iguazú, Argentina, pp. 155. [in Spanish]

Campbell DG, Stone JL, Arito Rosas JR (1992). A comparison of the phytosociology and dynamics of three floodplain (Várzea) forests of known ages, Rio Juruá, western Brazilian Amazon. Botanical Journal of the Linnean Society 108 (3): 213-237. - doi: 10.1111/j.1095-8339.1992. tboo240.x

Campos JB, Souza MCD (2002). Arboreous vegetation of an alluvial riparian forest and their soil relations: Porto Rico island, Paraná river, Brazil. Brazilian Archives of Biology and Technology 45 (2): 137-149. - doi: 10.1590/S1516-891320020002 00004

Casco SL, Neiff M, Neiff J J (2005). Biodiversidad en ríos del litoral fluvial. Utilidad del software PULSO [Biodiversity in rivers of the fluvial littoral. Usefulness of the PULSO software]. Miscelánea - INSUGEO 14 (2): 419-434. [in Spanish] Cline SP, McAllister LS (2012). Plant succession after hydrologic disturbance: Inferences from contemporary vegetation on a chronosequence of bars, Willamette River, Oregon, USA. River Research and Applications 28 (9): 15191539. - doi: 10.1002/rra.1539

Corenblit D, Tabacchi E, Steiger J, Gurnell AM (2007). Reciprocal interactions and adjustments between fluvial landforms and vegetation dynamics in river corridors: a review of complementary approaches. Earth-Science Reviews 84: 56-86. - doi: 10.1016/j.earscirev.2007. 05.004

De Oliveira AC, Piedade MTF (2002). Population structure of Salix martiana Willd. (Salicaceae) in whitewater floodplain areas of Central Amazonia, Brazil. In: "Neotropical Ecosystems. Proceedings of the German-Brazilian Workshop". Hamburg (Germany), 3-8 Sept 2000. GKSS, Geesthacht, Germany, pp. 917-921. [online] URL: http://www.researchgate.net/publication/ 27271333

Eskuche UG (2004). La vegetación de la vega del río Paraná medio superior, Argentina [The vegetation of the flood-plain of the river Paraná medio superior, Argentina]. Folia Botanica et Geobotanica Correntesiana 17: 3-59. [in Spanish]

Franceschi EA, Prado DE, Lewis JP (1985). Comunidades vegetales y mapa de vegetación: 
Reserva “El Rico" e islas aledañas, Provincia de Santa Fe, Argentina [Plant communities and vegetation map: "El Rico" reserve and surrounding islands, Santa Fe Province, Argentina]. Editora de la Universidad Nacional de Rosario, Rosario, Argentina, pp. 40. [in Spanish]

Fritschy BA (2004). El bosque de albardón en la geofacies del lecho ordinario del río Paraná Medio. Transecta Santa Rosa-Pueblo Brugo, Santa Fe, Argentina [The levee forest in the geofacies of the Middle Paraná river floodplain. Santa Rosa-Pueblo Brugo transect, Santa Fe, Argentina]. In: Proceedings of the Workshop "V Jornadas Nacionales de Geografía Física". Santa Fe (Argentina), 15-19 Sept 2004. Universidad Católica de Santa Fe, Santa Fe, Argentina, pp. 85-94. [in Spanish]

Gotelli NJ, Chao A (2013). Measuring and estimating species richness, species diversity, and biotic similarity from sampling data. In: "Encyclopedia of Biodiversity, vol. 5" (Levin S ed). Academic Press, Waltham, MA, USA, pp. 195211. - doi: 10.1016/B978-0-12-384719-5.00424-X

Gurnell AM, Petts GE, Hannah DM, Smith BPG, Edwards PJ, Kollmann J, Ward JV, Tockner K (2001). Riparian vegetation and island formation along the gravel-bed Fiume Tagliamento, Italy. Earth Surface Processes and Landforms 26: 31-62. - doi: 10.1002/1096-9837(200101)26:1 <31::AID-ESP155>3.0.CO;2-Y

Halffter G, Moreno CE (2005). Significado biológico de las diversidades alfa, beta y gamma [Biological meaning of the alpha, beta and gamma diversity]. In: "Sobre diversidad biológica: el significado de las diversidades alfa, beta y gamma" (Halffter G, Soberón J, Koleff P, Melic A eds). Sociedad Entomológica Aragonesa, Zaragoza, Spain, pp. 5-18. [in Spanish]

Hill MO (1973). Diversity and evenness: a unifying notation and its consequences. Ecology 54 (2): 427-432. - doi: 10.2307/1934352

Hothorn T, Hornik K, Van De Wiel MA, Zeileis A (2006). A Lego system for conditional inference. The American Statistician 60 (3): 257-263. - doi: 10.1198/000313006X118430

Hsieh TC, Ma KH, Chao A (2016). iNEXT: an R package for interpolation and extrapolation of species diversity (Hill numbers). Methods in Ecology and Evolution 7 (12): 1451-1456. - doi: 10.1111/2041-210X.12613

Hupp CR, Osterkamp WR (2013). Vegetation ecogeomorphology, dynamic equilibrium and disturbance. In: "Treatise on Geomorphology, vol. 12, Ecogeomorphology” (Shroder JF, Butler DR, Hupp CR eds). Academic Press, San Diego, CA, USA, pp. 94-106. - doi: 10.1016/B978-0-12-3747 39-6.00324-9

Jokinen P, Tuukki E, Kalliola R, Sarmiento A (1996). Vegetación en terrenos de diferentes edades en las islas del alto río Amazonas, Perú [Vegetation on lands of different ages in the islands of the upper Amazon River, Peru]. Folia Amazonica 8 (2): 121-140. [in Spanish] - doi: 10.24841/fa.v8i2.325

Kandus P, Malvárez Al (2004). Vegetation patterns and change analysis in the lower delta islands of the Paraná River (Argentina). Wetlands 24 (3): 620-632. - doi: 10.1672/0277-5212 (2004)024[0620:VPACAI]2.0.CO;2

Kandus P (1999). El concepto de sucesión primaria en sistemas deltaicos [The primary suc- cession concept in deltaic systems]. In: “Tópicos sobre humedales subtropicales y templados de Sudamérica" (Málvarez Al ed). UNESCO, Montevideo, Uruguay, pp. 173-188.

Kollmann J, Vieli M, Edwards PJ, Tockner K, Ward JV (1999). Interactions between vegetation development and island formation in the Alpine river Tagliamento. Applied Vegetation Science 2 (1): 25-36. - doi: 10.2307/1478878

Latrubesse E (2008). Patterns of anabranching channels: the ultimate end-member adjustment of mega rivers. Geomorphology 101: 130145. - doi: 10.1016/j.geomorph.2008.05.035

Lewis JP, Franceschi EA (1979). Notas sobre la dinámica de la vegetación del valle del Río Paraná [Notes on the vegetation dynamics of the Paraná River valley]. Ecosur 6 (12): 145-163. [in Spanish]

Liotta J (2001). Rasgos biológicos de Salix humboldtiana Willd. y régimen de pulsos de inundación [Biological traits of Salix humboldtiana Wild. and flood pulse regime]. Interciencia 26 (9): 397-403. [in Spanish]

Marchetti ZY, Aceñolaza PG (2012). Pulse regime and vegetation communities in fluvial systems: the case of the Paraná River floodplain, Argentina. Flora 207 (11): 795-804. - doi: 10.1016/j. flora.2012.09.004

Marchetti ZY, Latrubesse EM, Pereira MS, Ramonell CG (2013). Vegetation and its relationship with geomorphologic units in the Paraná River floodplain, Argentina. Journal of South American Earth Sciences 46: 122-136. - doi: 10.1016/j.jsames.2013.03.010

McCune B, Grace JB (2002). Analysis of ecological communities. MjM Software Design, Gleneden Beach, OR, USA, pp. 304.

McCune B, Mefford MJ (2011). PC-ORD: multivariate analysis of ecological data (version 6). Gleneden Beach, OR, USA, pp. 28.

Morello J (1949). Las comunidades vegetales de las islas cercanas al Puerto de Rosario [Plant communities in the islands near the Port of Rosario]. PhD Thesis, Universidad Nacional de La Plata, La Plata, Argentina, pp. 244. [in Spanish]

Müller-Dombois D, Ellenberg H (1974). Aims and methods of vegetation ecology. Wiley. New York, NY, USA, pp. 547.

Neiff JJ, Neiff M (2003). PULSO, software para análisis de fenómenos recurrentes [PULSO, software for the recurrent phenomena analysis]. Dirección Nacional de Derecho de Autor no. 236164, Buenos Aires, Argentina [in Spanish] [online] URL: http://www.neiff.com.ar Neiff JJ, Reboratti HJ (1989). Estructura y dinámica de bosques de Tessaria integrifolia II: análisis del crecimiento y productividad [Structure and dynamics of Tessaria integrifolia forests II: analysis of growth and productivity]. Boletín de la Sociedad Argentina de Botánica 26 (1-2): 3943. [in Spanish]

Neiff JJ (1986). Aquatic plants of the Paraná system. In: "The Ecology of River Systems" (Davies BR, Walker KF eds). Springer, Dordrecht, Netherlands, pp. 557-571.

Neiff JJ (2004). Bosques fluviales de la cuenca del Paraná [Fluvial forests of the Paraná basin]. In: "Ecología y Manejo de los Bosques de Argentina” (Goya JF, Frangi JL, Arturi MF, eds.). Editorial de la Universidad Nacional de La Plata
(EDULP), La Plata, Argentina, pp. 1-26. Oksanen J, Blanchet FG, Friendly M, Kindt R, Legendre $P$, McGlinn D, Minchin PR, O'Hara RB, Simpson GL, Solymos P, Stevens MHH, Szoecs E, Wagner H (2018). vegan: community ecology package. R package version 2:5-3. [online] URL: http://CRAN.R-project.org/package=vegan

Oliveira-Wittmann A, Piedade MT, Parolin P, Wittmann F (2007). Germination in four lowvárzea tree species of Central Amazonia. Aquatic Botany 86 (3): 197-203. - doi: 10.1016/j. aquabot.2006.10.001

Parolin P, Lucas C, Piedade MT, Wittmann F (2010). Drought responses of flood-tolerant trees in Amazonian floodplains. Annals of Botany 105 (1): 129-139. - doi: 10.1093/aob/mcp258

Pereira MS (2016). El Río Paraná: geomorfología y morfodinámica de barras e islas de un gran río anabranching [The Paraná River: geomorphology and morphodynamics of bars and islands of a large anabranching river]. PhD Thesis, Universidad Nacional de La Plata, La Plata, Argentina, pp. 381. [in Spanish]

Pickett ST, Cadenasso ML, Meiners SJ (2013). Vegetation dynamics. In: "Vegetation ecology" (Van Der Maarel E, Franklin J eds). Wiley-Blackwell, Oxford, UK, pp. 107-135. - doi: 10.1002/ 9781118452592.ch4

R Core Team (2017). R: a language and environment for statistical computing. R Foundation for Statistical Computing, Vienna, Austria. [online] URL: http://www.r-project.org

Ramonell CG, Szupiany RN, Latrubesse EM, García M, Pereira MS, Gallego MG, Marchetti ZY, Cafaro ED, Paira AR, Latosinski F, Bosisio AC, Torres G (2011). Procesos de formación del Río Paraná Medio. Nuevos paradigmas para su estudio [Formation processes of the Middle Paraná River. New paradigms for its study]. In: Proceedings of the Workshop "Ríos 2011: Hidráulica Fluvial: Procesos de Erosión y Sedimentación, Obras de control y Gestión de ríos". Santiago del Estero (Argentina), 2-4 Nov 2011. Alejandría editora, Córdoba, Argentina, pp. 1-14. [in Spanish]

Shin N, Nakamura F (2005). Effects of fluvial geomorphology on riparian tree species in Rekifune River, northern Japan. Plant Ecology 178: 15-28. - doi: 10.1007/s11258-004-2484-9

Sitzia T, Picco L, Ravazzolo D, Comiti F, Mao L, Lenzi, MA (2016). Relationships between woody vegetation and geomorphological patterns in three gravel-bed rivers with different intensities of anthropogenic disturbance. Advances in Water Resources 93: 193-204. - doi: 10.1016/j.advwatres.2015.11.016

Stella JC, Hayden MK, Battles JJ, Piégay H, Dufour S, Fremier AK (2011). The role of abandoned channels as refugia for sustaining pioneer riparian forest ecosystems. Ecosystems 14 (5): 776-790. - doi: 10.1007/s10021-011-9446-6 Thorp JH, Thoms MC, Delong MD (2006). The riverine ecosystem synthesis: biocomplexity in river networks across space and time. River Research and Applications 22 (2): 123-147. - doi: 10.1002/rra.901

Tichy L, Chytry M (2006). Statistical determination of diagnostic species for site groups of unequal size. Journal of Vegetation Science 17 (6): 809-818. - doi: 10.1111/j.1654-1103.2006.tb02504. 
Toniolo HA (1999). Las divagaciones del thalweg del río Paraná [The divagations of the Paraná River thalweg]. MSc Thesis, Universidad Nacional del Litoral, Santa Fe, Argentina, pp. 175. [in Spanish]

Walker LR, Wardle DA, Bardgett RD, Clarkson BD (2010). The use of chronosequences in studies of ecological succession and soil development. Journal of Ecology 98 (4): 725-736. - doi: 10.1111/ j.1365-2745.2010.01664.x

Wheaton JM, Gibbins C, Wainwright J, Larsen L, McElroy B (2011). Preface: multiscale feedbacks in ecogeomorphology. Geomorphology 126 (3): 265-268. - doi: 10.1016/j.geomorph.2011.01.002

Wittmann F, Schöngart J, Junk WJ (2010). Phytogeography, species diversity, community structure and dynamics of central Amazonian floodplain forests. In: "Amazonian floodplain forests" (Junk WJ, Piedade MTF, Wittmann F, Schöngart J, Parolin $P$ eds). Springer, Dordrecht, Netherlands, pp. 61-102. - doi: 10.1007/ 978-90-481-8725-6_4

Worbes M, Klinge H, Revilla JD, Martius C (1992). On the dynamics, floristic subdivision and geo- graphical distribution of várzea forests in Central Amazonia. Journal of Vegetation Science 3 (4): 553-564. - doi: $10.2307 / 3235812$

Zuloaga FO, Belgrano MJ (2015). The catalogue of vascular plants of the southern cone and the flora of Argentina: their contribution to the World Flora. Rodriguésia 66 (4): 989-1024. - doi: $10.1590 / 2175-7860201566405$

\section{Supplementary Material}

Appendix 1 - Botanical sources and references.

Appendix 2 - Further details on R package and functions.

Fig. S1 - Proportion of life forms.

Fig. S2 - Field photos and remarkable features of forests in the oldest bar of each of the Young Islands (YI).
Fig. S3 - Field photos and remarkable features of forests in the oldest bar of each of the Old Islands (OI).

Tab. S1 - Cartographic and satellite imagery sources.

Tab. S2 - Floristic checklist of the registered taxa arranged systematically.

Tab. S3 - Species list of the Young Island forests according to the Species Indicator Analysis.

Tab. S4 - Species list of the Old Island forests according to the Species Indicator Analysis.

Link: Brumnich_2737@supploo1.pdf 